\title{
Accessibility to urgent and emergency care services in low-density territories: the case of Baixo Alentejo, Portugal
}

\author{
Acessibilidade à rede de serviços de urgência em territórios de baixa \\ densidade: o caso do Baixo Alentejo, Portugal
}

Rita Ferreira (https://orcid.org/0000-0002-7937-9521)

Nuno Marques da Costa (https://orcid.org/0000-0003-4859-9668) ${ }^{1}$

Eduarda Marques da Costa (https://orcid.org/0000-0001-5070-3562) ${ }^{1}$

${ }^{1}$ Instituto de Geografia e Ordenamento do Território (IGOT), Universidade de Lisboa. Edifício IGOT, Rua Branca Edmée Marques. 1600-276 Lisboa Portugal. rferreira11@campus.ul.pt

\begin{abstract}
Access to health care is a sensitive issue in low population density territories, as these areas tend to have a lower level of service provision. One dimension of access is accessibility. This paper focuses on measuring the accessibility to urgent and emergency care services in the Portuguese region of Baixo Alentejo, a territory characterized by low population density. Data for the calculation of accessibility is the road network, and the methodology considers the application of a two-level network analyst method: time-distance by own mean (car or taxi) to the urgent care services and the time distance to emergency services as a way to get assistance and to go to urgent care services. While urgent care accessibility meets the requirements stipulated in the Integrated Medical Emergency System's current legislative framework, the simulation of different scenarios of potential accessibility shows intra-regional disparities. Some territories have a low level of accessibility. Older adults, the poorly educated, and low-income population, also have the lowest levels of accessibility, which translates into dually disadvantageous situation since the potential users of emergency services are most likely to belong to this group of citizens.
\end{abstract}

Key words Accessibility, Urgent care Services, Emergency Ambulance Service, Low-Density Areas
Resumo Em territórios de baixa densidade populacional, o acesso aos cuidados de saúde é uma questão delicada, pois essas áreas tendem a ter um nível mais baixo de prestação de serviços. Uma dimensão do acesso é a medição da acessibilidade. Este artigo tem como propósito medir a acessibilidade aos serviços de urgência e aos meios de emergência médica na região portuguesa do Baixo Alentejo, território caracterizado por uma baixa densidade populacional. A metodologia considera o método network analyst aplicado à rede viária, em dois níveis: o cálculo da distância-tempo aos serviços de urgência usando modo próprio (carro ou táxi); e o cálculo da distânciatempo recorrendo aos meios de socorro e emergência como forma de aceder aos serviços de urgência. Embora se considere que a acessibilidade às urgências atende ao atual quadro legislativo do Sistema Integrado de Emergência Médica, a simulação de diferentes cenários no Baixo Alentejo mostra a existência de disparidades intra-regionais no que se refere à acessibilidade aos serviços de urgência. Verifica-se que é a população idosa, de baixa instrução e residente em zonas com baixa densidade populacional quem apresenta menores indices de acessibilidade, o que traduz uma situação $d u$ plamente desvantajosa, uma vez que estes são os maiores utilizadores destes serviços.

Palavras-chave Acessibilidade, Serviços de Urgência, Meios de emergência, Áreas de baixa densidade 


\section{Introduction}

In the last decades, demographic and economic trends have favored urbanized territories in detriment of rural areas, primarily characterized by the lowest population densities, demographic decline, and a large share of older adults with limited mobility and low income. The access to health services in these territories becomes more relevant, as the decline of demand induced a growing scarcity of health services, especially the urgent and emergency care services. In this context, the studies related to equity in access gains importance in support of policy recommendations.

The concept of access to health care is a complex process, and for that reason, there are different perspectives on its definition or methods to be used. Some authors use the term "accessibility", while others prefer the term "access". Both refer to the way of obtaining health care services ${ }^{1,2}$.

The concept of accessibility refers to the facilities at the population's disposal, their means of transport, and the opportunities available to them $^{3-5}$, while other authors ${ }^{6}$ believe that accessibility has two components: one corresponds to the location of services and the population (higher for people that live close), and the second is related to personal mobility, depending on the transportation mode used to reach the service. A third perspective, accessibility is related to three dimensions: the territory, the population, and the services organization ${ }^{7}$ (p.106).

Initially, accessibility was related to the idea of proximity and facility of spatial interaction. However, as mentioned by several authors ${ }^{8-12}$, physical or geographical accessibility alone is insufficient to analyze inequalities in a population's access to several health care services ${ }^{13,14}$.

In this context, other economic, social, and environmental factors are mentioned by the various authors, which directly or indirectly influence the level of achieving health care. Indeed, access to health care has been the subject of discussion since the 1970s, showing an articulated and integrated approach of the several dimensions. At this stage, we could conclude that the concept of access is more comprehensive and embracing than acessibility ${ }^{6,13}$.

A 1981 study defined five dimensions of access: availability, accessibility, affordability, accommodation, and acceptability ${ }^{12}$. From this perspective, the dimension of availability is related to the (quantified) presence or absence of existing services, which can be measured by the type of equipment(s) and the number of available hu- man resources, namely doctors and nurses. For those authors, accessibility is the dimension of access that connects location and the geographic distribution of services and users. Affordability is related to the organization of the services and users' ability to adapt to this organization (comfort in use). Accommodation is based on the relationship between the service's use and the possibility of paying for that service. Finally, acceptability is related to the trust and satisfaction felt by professionals and users concerning the services ${ }^{12,15,16}$.

Whatever the perspective, there is a consensus that access to health care is regarded as a fundamental human right and a social goal because all individuals are entitled to health care $^{17} \mathrm{cit}$ in ${ }^{18}$, which obliges governments to create conditions for their provision. By definition, if access is the availability of an adequate supply of health care services and the individual's opportunity to obtain health care when it is wanted or needed ${ }^{18}$, the equity in access is met when health care is accessed according to the needs ${ }^{19}$ cit. in ${ }^{20}$.

We have been witnessing changes in the models of provision of services in the European context, showing a decline of the welfare perspective in favor of a more economical viewpoint. The health provision models favor privatization and the efficiency approaches, putting at risk the equity in access to all territories and social groups. Frequently, the areas with a higher concentration of older adults tend to have lower service provision levels, while densely urbanized areas tend to have a broader set of affordable services. However, they often face issues of lack of effectiveness, efficiency, or quality ${ }^{21}$.

For the European Union (EU), the concept of "Services of General Interest" (SGI) emerges as an alternative to the traditional definition of social services. They are defined as services that the Member States public authorities classify as being of general interest and where the providers are therefore entrusted with public service or universal service obligations, specially dedicated to economic services, which highlights the importance of the population accessing services, fulfilling equity conditions. To this end, the EU defines some conditions.

The Lisbon Treaty (EU, 2010, prot.26), expressed in the Protocol "On Services of General Interest", declares in the first article "the essential role and the wide discretion of national, regional and local authorities in providing, commissioning and organizing services of general economic interest as closely as possible to the needs of the users" ${ }^{15}$, highlighting citizen social rights and the 
need of territorial balance in the framework of $\mathrm{SGI}^{22}$. The European orientations for SGI played an essential role in ensuring the maintenance of dynamics in rural and peripheral territories ${ }^{15}$ since the Member States' public authorities classify these services as being of general interest. These services may be rendered either by the State or the private sector, to ensure that all citizens should have access to services, regardless of their social characteristics or geographical location ${ }^{22,23}$.

According to the Green Paper on Services of General Interest ${ }^{24}$, the SGI may assert themselves as an essential contribution to mitigating disparities between regions and are indispensable for the subsistence of rural or low-density territories and the small, medium-sized cities/villages located in rural and peripheral areas. These cities and villages ensure the provision of services to citizens of these regions, including the infrastructures required for investment in the adaptability of people and businesses ${ }^{15}$.

This paper aims to measure the accessibility of emergency services and medical emergency facilities in the Portuguese region of Baixo Alentejo, a territory characterized by low population density and weak economic activity. The methodology considers the network analyst method applied to the road network at two levels: the calculation of time-distance to emergency services (hospital and other centers) using own mobility mode (car or taxi); the calculation of time-distance using the National Emergency Medical Service (NIME) as a way to reach the emergency services.

It is also important to stress that, as referred in Order 18459/2006, of July 30, an "urgent or emergency case consists of a clinical situation with a sudden onset, with an actual or potential risk of one or more vital functions being compromised or failing". Thus, accessibility is essential since it is necessary to ensure the fastest response of emergency means and emergency services' best response capacity.

One question emerges: Is there equal accessibility to the urgent and emergency care resources distributed across the Baixo Alentejo region?

The presen $t$ work is structured in five parts. The first consists of the theoretical framework and the definition of the study's objectives. The second one describes the organization of the urgent care service and emergency system in Portugal and, in more detail, in Baixo Alentejo. The third part contains a description of the methodology, followed by a presentation of the results and its discussion in part four. The study ends with a concluding note.
The study area, the NUTS III of Baixo Alentejo, part of NUTS II Alentejo, is an aging region, classified in European statistical context as a low population density area (region composed by local administrative units (LAU 1), generally municipalities, with less than 150 inhabitants $/ \mathrm{km}^{2}$ and not located in an urban center ${ }^{25}$ ). We should bear in mind the relationship between aging and an increase in several chronic and incapacitating pathologies, such as strokes. These assumptions should be considered for health services, structuring, and responsiveness in a low population density context since the highest number of potential emergency services users is among older citizens.

\section{The urgent care and emergency services in mainland Portugal and Baixo Alentejo}

The National Emergency Services Network and the creation of basic emergency units were approved, respectively, on November 14, 2001, and February 7, 2002. Subsequently, Order 18.459/2006, of July 30, published in Diário da República [Official Gazette], $2^{\text {nd }}$ series, no. 176, of September 12, amended by Order 24681/2006, of October 25, and Order 5414/2008, of January 28, defined the characteristics of the Emergency Services Network, its levels of responsibility, criteria, conditions of access, and location of emergency network points.

Recently, Order 10319/2014, of August 11, determined the structure of the Integrated Medical Emergency System (IMES) concerning hospital responsibility and its interface with the pre-hospital services, with the levels of responsibility of the Urgent Care Services (UCS). It also established minimum standards regarding structure, human resources, criteria, and quality indicators, and defined a monitoring and evaluation process.

Three levels of reception have been defined for urgent care services. According to their degree of specificity, they should respond to a given population's urgent care situations, as shown in Chart 1.

The National Institute of Medical Emergency (NIME) is the entity in mainland Portugal responsible for the coordination and operation of the Integrated Medical Emergency System (IMES). All urgent care/emergency activities, including the pre-hospital emergency system, patient referral, transportation, and hospital reception, fall within the IMES scope.

In short, when the European emergency number (112) is called, the calls initially answered 
Chart 1 . Levels of Urgent Care Service in Portugal.

\begin{tabular}{|l|l|l|}
\hline \multicolumn{1}{|c|}{$\mathbf{1}^{\text {st }}$ Reception Level } & \multicolumn{1}{c|}{$\mathbf{2}^{\text {nd }}$ Reception Level } & \multicolumn{1}{c|}{$\mathbf{3}^{\text {rd }}$ Reception Level } \\
\hline Basic Urgent Care Service (BUS) & $\begin{array}{l}\text { Medical-Surgical Urgent care } \\
\text { Service (MSUS) }\end{array}$ & $\begin{array}{l}\text { Multipurpose Urgent care Service } \\
\text { (MUS) }\end{array}$ \\
\hline $\begin{array}{l}\text { Responding to more uncomplicated } \\
\text { urgent care and emergencies. } \\
\text { It assumes the patient's initial } \\
\text { stabilization for further referral to a } \\
\text { more differentiated level of care in } \\
\text { more complex situations. }\end{array}$ & $\begin{array}{l}\text { It responds to situations requiring } \\
\text { more differentiated care. Referral } \\
\text { to higher-level services situations } \\
\text { that require the support of specific } \\
\text { medical specialties. }\end{array}$ & $\begin{array}{l}\text { Responding to more complex } \\
\text { situations and having most } \\
\text { hospital valences. Some MUS } \\
\text { have Trauma Centers designed to } \\
\text { accommodate patients with more } \\
\text { severe issues. }\end{array}$ \\
\hline $\begin{array}{l}\text { This service should be available, } \\
\text { wherever deemed justified, to ensure } \\
\text { the access of a given population } \\
\text { within a maximum period of 60 } \\
\text { minutes (in the absence of a higher- } \\
\text { level urgent care service). }\end{array}$ & $\begin{array}{l}\text { Ranging from 20 to 39 MSUS or } \\
\text { according to a ratio of 2/3 per } \\
\text { MUS. It should be located at least } \\
\text { 60 minutes from another MSES or } \\
\text { MSE, except for cases where the } \\
\text { population covered by each hospital } \\
\text { exceeds 200,000 inhabitants. }\end{array}$ & $\begin{array}{l}\text { Ranging from 10 to 13 MUS or } \\
\text { according to a ratio of 1 MUS for }\end{array}$ \\
\hline $\begin{array}{l}\text { Life support ambulance - LSA } \\
\text { (ambulância de suporte imhabitants. } \\
\text { vida - SIV) is available. }\end{array}$ & $\begin{array}{l}\text { Emergency medical and } \\
\text { resuscitation vehicle - EMRS } \\
\text { (Viatura Médica de Emergência e } \\
\text { Reanimação - VMER) is available. }\end{array}$ & $\begin{array}{l}\text { Emergency medical and } \\
\text { resuscitation vehicle - EMRS } \\
\text { Reanimaçara - VMER) is available. }\end{array}$ \\
\hline
\end{tabular}

Source: Order 10319/2014, of August 11.

by the Public Security Police are forwarded to the Urgent Patient Orientation Centers in urgent or emergency medical situations. These Urgent Patient Orientation Centers perform the screening, counseling, and selection of the service to be triggered to relieve the victims. Screening aims to determine the appropriate means for each clinical situation and determine the type of health unit that will provide the necessary treatment. This procedure is based on decision algorithms approved by the Association of Physicians, whose mission is to give adequate treatment to distress calls based on clinical criteria ${ }^{26}$. Chart 2 shows the Emergency Services that operate from the road network and their location.

Concerning the case study area, Baixo Alentejo NUTS III, we have the Baixo Alentejo Local Health Unit (Baixo Alentejo LHU), including an area covered by the Alentejo Regional Health Administration, I.P. (ARS Alentejo).

Health care integration may be one of two options: vertical integration or horizontal integration $^{29}$. In vertical integration, a single entity is responsible for managing the services at the same healthcare level. On the other hand, horizontal integration involves the provision of multi-level health services, which means that a single entity is responsible for the health status of a given population, including the various types of health care - primary, hospital, continued, and palliative ${ }^{30}$.
In practice, it corresponds to the creation of Local Health Units (LHU), public business entities providing integrated primary, differentiated, and continued health care to the population residing in the geographical area they cover ${ }^{31}$.

The Local Health Units of Baixo Alentejo have three urgent care services, two of which are integrated into primary health care, referring to essential urgent care services (Castro Verde and Moura) and a medical-surgical urgent care service, located at the central hospital of José Joaquim Fernandes Hospital.

Based on NIME's information, we can conclude that there are 18 emergency facilities in this area. Of these, 5 Emergency Ambulances (EA) are in the reserve centers, 10 Emergency Medical Ambulance (EMA) in Emergency Medical Centers, 2 Immediate Life Support Ambulance (LSA) in the Castro Verde and Moura basic urgent care service, and 1 Emergency Medical and Resuscitation Vehicle (EMRS) at the Beja Hospital (Hospital with a Medical-Surgical Urgent care Service - MSUS).

Concerning the study area, Baixo Alentejo has a lower population density, and the population variation is negative in all municipalities, except Beja, which has the highest municipality population density of approximately 31.2 inhabitants/ $\mathrm{km}^{2}$. Nevertheless, this figure is considerably lower than the country's average (114.5 inhabitants/ 
Chart 2. Types of Emergency Ambulance Service in Portugal.

\begin{tabular}{|l|l|l|}
\hline \multicolumn{1}{|c|}{ Emergency Ambulance Service } & \multicolumn{1}{|c|}{ Description } & \multicolumn{1}{c|}{ Location } \\
\hline $\begin{array}{l}\text { Emergency ambulance - EA } \\
\text { (ambulância de Socorro - AS) }\end{array}$ & $\begin{array}{l}\text { Ensures the rapid response of a team with training } \\
\text { in emergency techniques to the scene. It acts in } \\
\text { conjunction with other pre-hospital services. }\end{array}$ & $\begin{array}{l}\text { Medical } \\
\text { emergency } \\
\text { points }\end{array}$ \\
\hline $\begin{array}{l}\text { Emergency medical Ambulance - } \\
\text { EMA (ambulância de emergência } \\
\text { médica - AEM) }\end{array}$ & $\begin{array}{l}\text { Ensures the rapid response of a pre-hospital medical } \\
\text { emergency team with training in emergency } \\
\text { techniques to the scene. }\end{array}$ & $\begin{array}{l}\text { NIME; MSUS; } \\
\text { MUS }\end{array}$ \\
\hline $\begin{array}{l}\text { Immediate life support ambulance - } \\
\text { LSA (ambulância de suporte imediato } \\
\text { de vida - SIV) }\end{array}$ & $\begin{array}{l}\text { Ensures more differentiated care, such as } \\
\text { resuscitation maneuvers in a pre-hospital } \\
\text { environment. }\end{array}$ & BUS \\
\hline $\begin{array}{l}\text { Emergency medical and resuscitation } \\
\text { vehicle - EMRS (Viatura Médica de } \\
\text { Emergência e Reanimação - VMER) }\end{array}$ & $\begin{array}{l}\text { Ensures pre-hospital stabilization and medical } \\
\text { follow-up during the transportation of accident } \\
\text { victims. }\end{array}$ & $\begin{array}{l}\text { MSUS and } \\
\text { MUS }\end{array}$ \\
\hline
\end{tabular}

Source: NIME ${ }^{26-28}$.

$\mathrm{km}^{2}$, according to the 2011 Census). In the last Census, the aging rate registered in Baixo Alentejo was $188.8 \%$, which shows that this is an aged territory. The study area population has a high illiteracy rate and an unemployment rate higher than the national average $(13.2 \%$ at the national level and 14.4\% in Baixo Alentejo).

The urban system of Baixo Alentejo tends to have a monocentric configuration. Nevertheless, secondary poles play an essential role at population and functional levels, resulting in population dispersion. The city of Beja is the only major center (the only city with over 10,000 inhabitants). We have secondary centers, such as the cities of Moura and Serpa and the villages of Aljustrel, Castro Verde, and Ferreira do Alentejo (Figure 1).

\section{Methods}

The methodology underlying the calculation of accessibility results from applying the service area algorithm (network analyst), which allows calculating the range of a given location from a constraint factor ${ }^{32}$.

The primary data structure for the calculation of accessibility is the road network. The fundamental national network that may be observed in Figure 1 includes three connections: A2/IP1 (Valença-Castro Marim), which vertically crosses the territory of Ferreira do Alentejo, Aljustrel, Castro Verde, Ourique and Almodôvar; IP2 (Po rtelo - Faro), also of a vertical profile; IP8 (Sines - Vila Verde do Ficalho) a horizontal connection between Sines and Vila Verde de Ficalho. The complementary national road network with IC
27 (Beja - Castro Marim) and the national road throughout the territory (besides other lower-level municipal roads) were also considered for this calculation.

After validating the road network and creating the time-distance field, which corresponds to the restriction factor, a network dataset and a service area were created. Network locations are points corresponding to the urgent care services and emergency facilities in the study area. The defined parameters enabled creating accessibility intervals (Isochrones) concerning a given urgent care service or emergency means (NIME ambulances). Thus, the time required from the emergency means to the user, and the user to the urgent care services was counted. Subsequently, accessibility was crossed with the sociodemographic data of the geographic information referencing base of the National Institute of Statistics. The mean density in each statistical subsection was calculated for all variables considered. Absolute numbers were not used to not overlap the population after cutting and intersecting statistical subsections with accessibility polygons.

\section{Results and Discussion}

\section{Step 1 - Access to emergency services by own road mode}

In the initial analysis, accessibility was calculated, considering the three urgent care services. The minimum requirement for any inhabitant to be 60 minutes at most from a BUS or a higher-level urgent care service was found to be fulfilled. Approximately $38 \%$ of the population of 


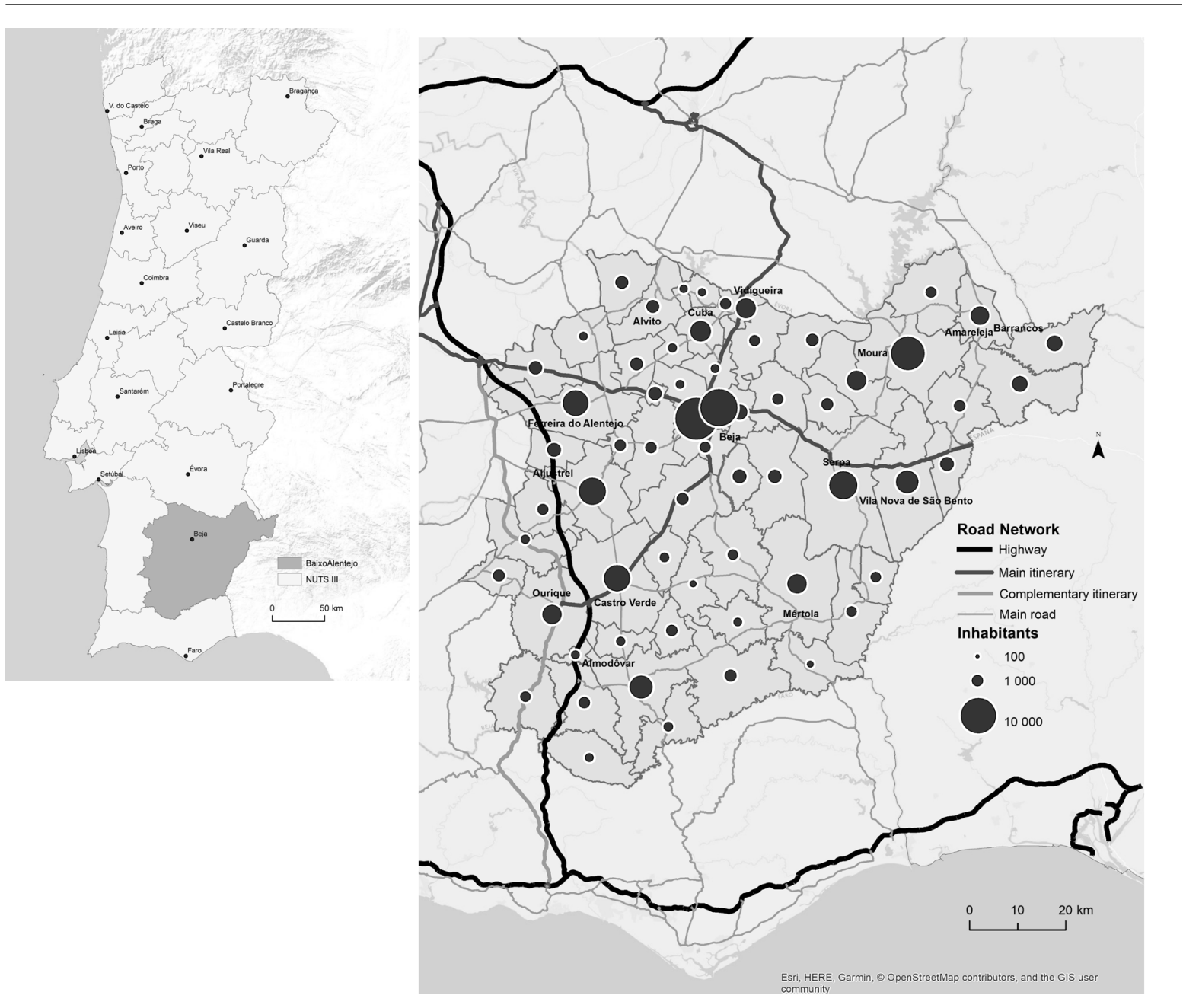

Figure 1. Baixo Alentejo Region - Location, Resident population by municipality and road network by category, 2018.

Source: Elaborated from INE, RGP data, 2011.

Baixo Alentejo access less than 10 minutes by car to one of the urgent care services, and no inhabitant needs more than 50 minutes to access one of the services (Figure 2).

The methodology applied also enabled us to draw some conclusions regarding the characteristics of the population. Considering the analysis by age structure, we find that the elderly population has a lower accessibility rate (Table 1 ). Simultaneously, we identified that the population furthest from urgent care services was also the least academically educated population. There was also a lower percentage of the employed population and a higher percentage of the retired population.

It is important to ascertain whether there are complementary means of diagnosis such as
X-ray, a computed tomography scan (CT Scan), or a magnetic resonance image (MRI), which enable the diagnosis of fractures, infections, and pneumonia, among other common pathologies in acute episodes.

In an interview with the Director of the urgent care service LHU of Baixo Alentejo, we confirmed that the basic urgent care service does not have a CT Scan or MRI but only an X-ray. Although the Castro Verde X-ray service is open 24 hours a day, the Moura X-ray service is only open between $8 \mathrm{am}$ to $8 \mathrm{pm}$. Therefore, accessibility is significantly reduced at night because the service in Moura is not available.

However, it should be noted that there are differences in the services provided: the basic urgent care service of Castro Verde and Moura 
Table 1. Accessibility (time-distance) of the resident population, by age group, to urgency health care services in Baixo Alentejo, 2018.

\begin{tabular}{cccc}
\hline $\begin{array}{c}\text { Accessibility } \\
\text { intervals } \\
\text { (time in } \\
\text { minutes) }\end{array}$ & $\begin{array}{c}\text { Young } \\
\text { population } \\
(\%)\end{array}$ & $\begin{array}{c}\text { Adult } \\
\text { population } \\
(\%)\end{array}$ & $\begin{array}{c}\text { Elderly } \\
\text { population } \\
(\%)\end{array}$ \\
\hline$<10$ & 43 & 40 & 32 \\
$<20$ & 80 & 77 & 71 \\
$<30$ & 95 & 94 & 91 \\
$<40$ & 99 & 99 & 99 \\
$<50$ & 100 & 100 & 100 \\
\hline
\end{tabular}

Source: Elaborated from data INE-RGP; DGS.

respond to more straightforward emergencies, while the Beja Medical-Surgical Urgent care Service (MSUS) is characterized by providing services of greater technical specificity. The population living in Beja and the closest areas to that municipality benefit most from its location. On the other hand, the population living in Barrancos and the southern area of Almodôvar, Ourique, and Mértola have the lowest accessibility rate to MSUS by car. Around $24 \%$ of the pop- ulation live less than 10 minutes away, and $61 \%$ of the population can reach the Medical-Surgical Urgent care Service (MSUS) by car in 30 minutes or less. However, $2 \%$ of the population live 60 to 80 minutes away from the MSUS.

Greater geographical proximity to the Alentejo was considered, namely Beja Hospital and Faro Hospital, when calculating the accessibility of an urgent care service of a higher level represented by the two multipurpose urgent care services. In this case, $10 \%$ of the population required 30 minutes or less to travel to one of these services. In contrast, approximately $14 \%$ of the population take 60 minutes or more to access a MUS.

\section{Step 2 - Accessibility of NIME's medical emergency facilities to the population}

Initially, the accessibility of the Emergency Ambulance Service (NIME) network to the resident population was based on the assumption that all existing means can be activated, regardless of the specificity associated with each ambulance. In this context, the time-distance coverage is quite good since $85 \%$ of the population have an ambulance less than 10 minutes away, and 
$99 \%$ of the population 20 minutes or less. On the other hand, and in the case of a more urgent situation requiring the activation of an Immediate Life Support Ambulance (LSA) or an Emergency Medical and Resuscitation Vehicle (EMRS), the situation is similar to that calculated for accessibility to existing urgent care services, since the NIME means are located in the same units.

The streamlined situation (Figure 3), which includes all emergency means and urgent care services, suggests that approximately $31 \%$ of the population can access the nearest urgent care service in less than 10 minutes and $24 \%$ require only 10 to 20 minutes. On the other hand, $20 \%$ of the population takes more than 30 minutes to access the service. The elderly population is in the most disadvantageous situation as the highest proportion of these people lives within the farthest accessibility range.
In situations that require more specialized and urgent care, users are forwarded to higher-level urgent care services and not to the nearest ones, where only $32 \%$ of the population can access the service in less than 20 minutes and 6\% take over 1 hour by one of the 18 means. The calculations also enabled us to verify that the "corridors" of greater accessibility are located between the Hospital of Beja and the emergency means of the municipalities Ferreira do Alentejo, Alvito, Cuba, Vidigueira, Serpa, and Aljustrel.

Finally, based on the two previous analyses, we analyzed a third scenario, which involves using NIME emergency means to access urgent care services (Figure 4).

On the other hand, the situation is even more worrying if only Immediate Life Support Ambulance (LSA) and Emergency medical and resuscitation vehicle (EMRS) are considered: although

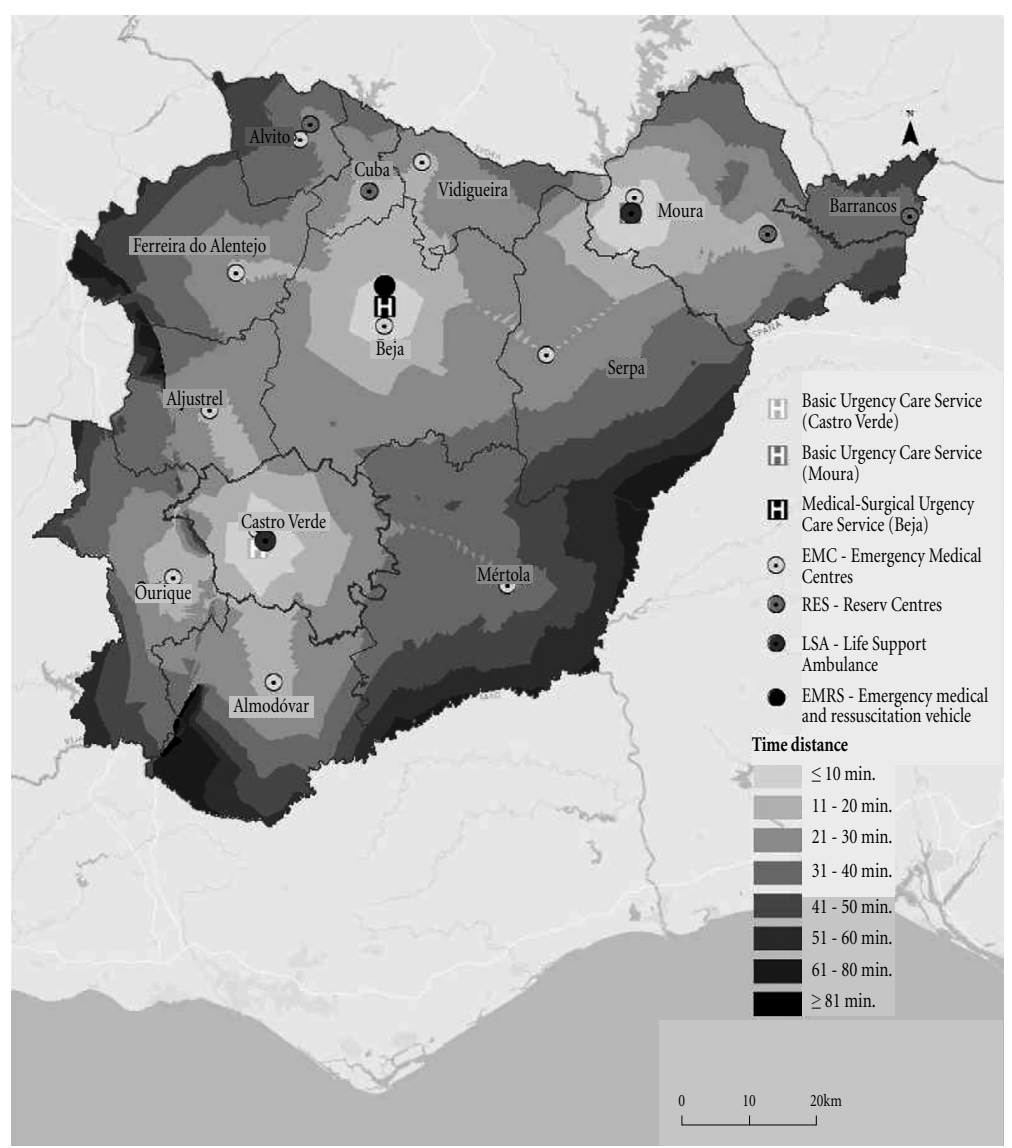

Figure 3. Accessibility (time-distance) to urgent care service by NIME emergency means, 2018. 


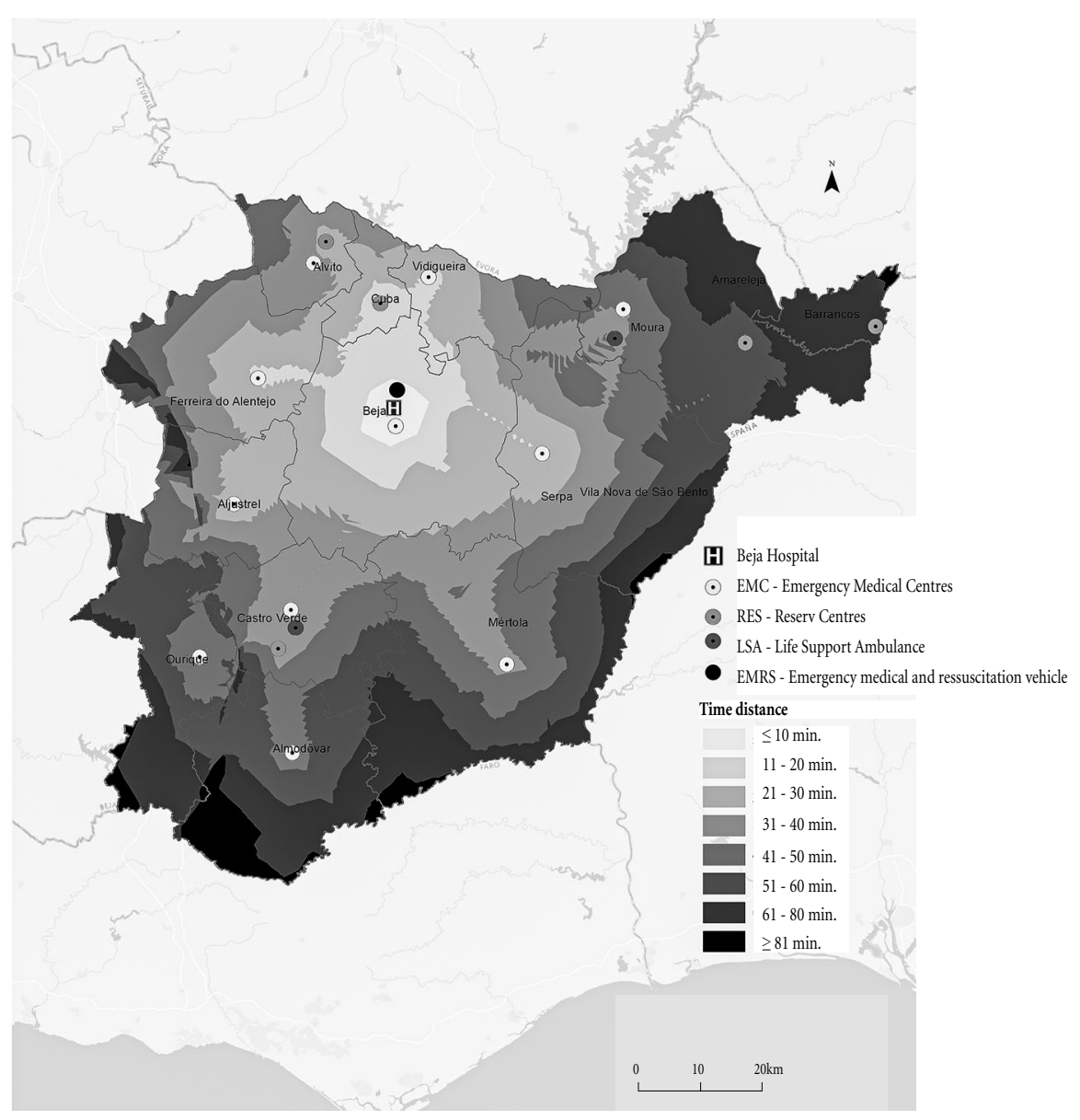

Figure 4. Accessibility (time-distance) to medical-surgical urgent care service by NIME emergency means, 2018.

Source: Elaborated from data INE-RGP; DGS; NIME.

$21 \%$ of the population can access Medical-Surgical Urgent care Service in less than 10 minutes, around $70 \%$ of the population require more than 30 minutes. Of these, $2 \%$ need more than 1 hour 30 minutes to reach an MSUS (Figure 5).

The last analysis assumes that the patient is referred to a Multipurpose Urgent care Service (MUS), which corresponds to the emergency services network's most differentiated level. In this case, only $1 \%$ of the population was observed to live within 30 minutes of a BUS using one of the 18 existing means of transport, and $47 \%$ took 60 minutes or more to reach that service (Figure 6).

As mentioned above, the emergency means may be activated by the European number by any citizen whenever their condition renders autonomous travel by private car or public transport unfeasible.
In Table 2, we can observe the six calculated scenarios regarding the accessibility of the population to urgent care services using a NIME ambulance.

The calculation showed the best results included using all the means of pre-hospital emergency in the study area (18 in total and at least one per municipality) to one of the three existing urgent care services (scenario 1).

In the cases requiring more differentiated care, patients are not referred to a basic urgent care service but to medical-surgical urgent care service or multipurpose urgent care service (scenarios 5 and 6). In this situation, accessibility is most unfavorable and may require more significant effort on the urgency means in the patient's initial stabilization, namely heart attack, ischemia, asthma attacks, childbirth, or accidents. 


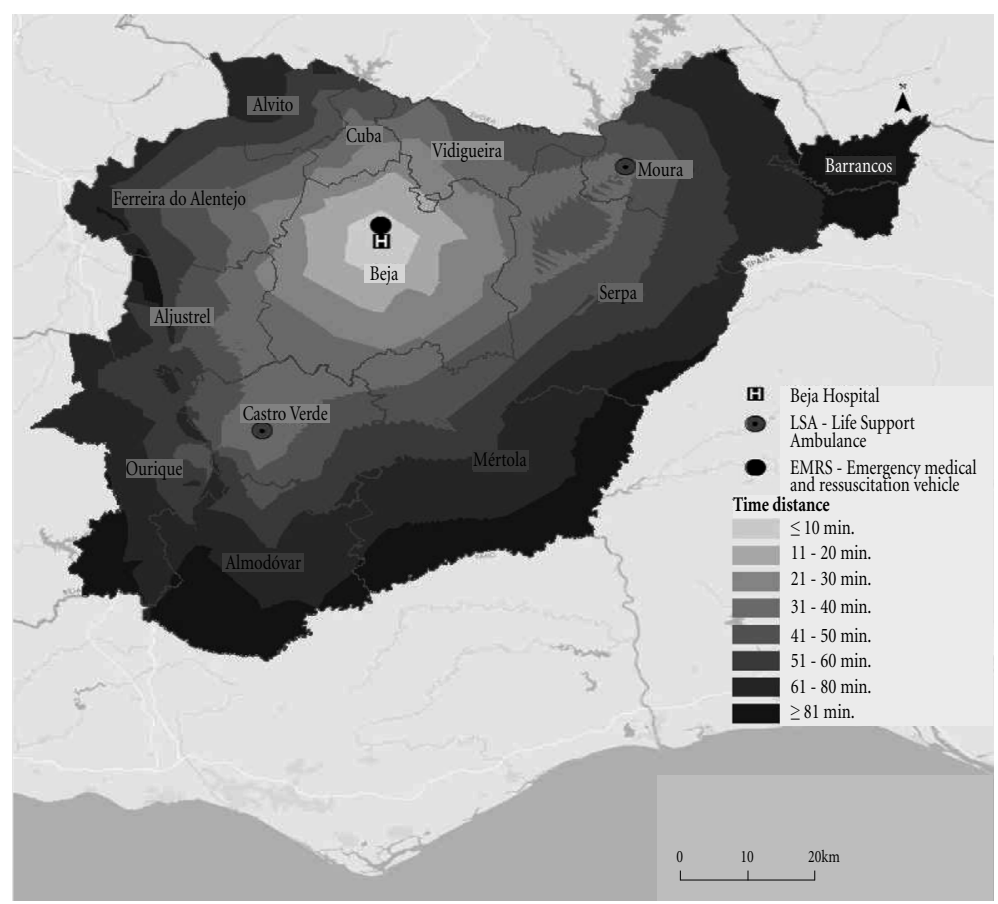

Figure 5. Accessibility (time-distance) to a medical-surgical urgent care service from a NIME Immediate Life Support Ambulance (LSA) and Emergency Medical and Resuscitation Vehicle (EMRS), in Baixo Alentejo, 2018.

Source: Elaborated from data INE-RGP; DGS; NIME.

The lowest accessibility rate areas correspond to municipalities that are farthest from Moura-Beja-Castro Verde, such as Barrancos, the southern border area, which includes the municipalities of Serpa and Mértola.

\section{Conclusions}

The unequal distribution of health services between urban and rural areas has been highlighted for most countries and cuts across health systems and countries in Europe. Frequently, local politicians and residents resist closing hospitals or primary care services in rural or remote areas. Nevertheless, besides the efficiency costs, we know that the quality of healthcare provision requires a specific concentration of knowledge and experience, which is hard to guarantee in remote and sparsely populated areas. There is a public policy tendency of concentrating highly specialized services to combine efficiency and quality. However, the concentration of services means lower accessibility and lower access in low-density areas.
For this case study, we observed that the accessibility dimension is, in theory, ensured, considering the minimum standards referred to throughout the legislation to provide services in the urgent care and emergency services. Although many users travel to an urgent care service in their cars, an essential share of the regional population with a high aging rate, low education level, and purchasing power below the national average does not have this privilege. This differentiated pattern retreats age, socio-economic and territorial inequalities in access to health care.

In practical terms, we can conclude that, with available equipment to provide the services, there is not always real availability to access and use them. For example, there was no X-ray service in Moura basic urgent care service during the night period. Thus, the pre-defined by law accessibility is not guaranteed in 24 hours a day, and the access in minimal time to emergency services is not assured. On the other hand, when placed as extreme conditions of need for a medical emergency (LSA and EMRS) and support for higher-level hospital urgency (Multipurpose Urgent 


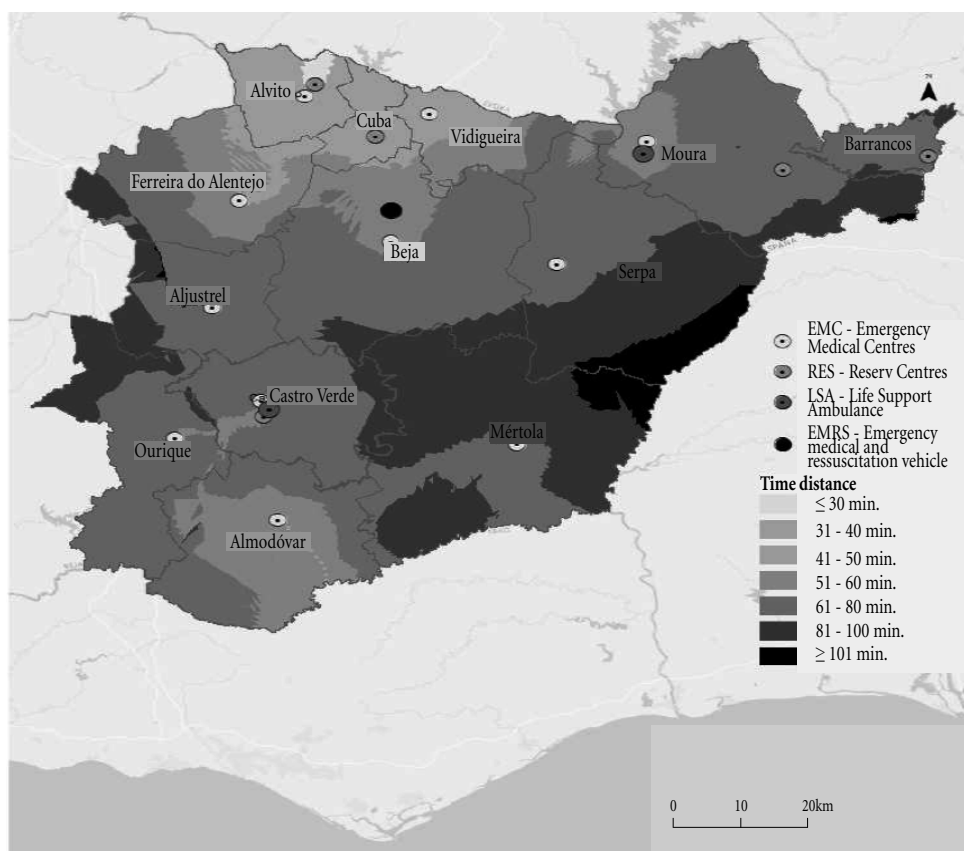

Figure 6. Accessibility (time-distance) to a multipurpose urgent care service by a NIME emergency means, in Baixo Alentejo, 2018.

Source: Elaborated from data INE-RGP; DGS; NIME.

care Service-MUS), only $42 \%$ of the population is attended within 60 minutes, while it takes up to 80 minutes to cover $70 \%$ of the population's demand in the region. Considering the full coverage of the region ( $100 \%$ of the resident population), the service could take until 130 minutes, which means more than 2 hours, to get support in an urgent situation.

On the other hand, it is troubling to see that older adults have the lowest accessibility rates, and there are still a high number of residents with little or no education, especially in the more peripheral areas. This elderly population, for the reasons mentioned above, is in a more disadvantageous situation due to the lower capacity of these citizens for autonomous travel and consequently their greater dependence on public transport, relatives, or emergency means. Inequalities in access to "urgent" health care are reinforced, as this is also the population that resorts most to these services while also being further away from them.

The work developed shows the need to rethink the provision of health services and, in particular, emergency and medical urgency in low-density territories. It does not mean that there should be an increase in hospitals in the region, but instead to ensure that the population accesses the existing services quickly and efficiently. We have three possibilities.

First of all, we can think of a reorganization of the service's areas of influence. While the Portuguese health system is organized by regions, we can suggest to generalize the possibility to refer users immediately to other hospitals or services (from other regions) that can respond to the emergency. This possibility means that screening is essential for referral cases, and time is not wasted traveling between health services that cannot respond to a particular situation. The second note relates to the need to better articulate the emergency means and the various hospitals, and guarantee the availability of physical resources (such as means of diagnosis and therapy) and human resources (health professionals). This reinforcement may not represent replication of means but strengthening communication developed with e-health solutions. 
Table 2 . Emergency service network accessibility intervals from an emergency (2018).

\begin{tabular}{|c|c|c|c|c|c|c|c|c|c|c|c|c|}
\hline \multirow[t]{3}{*}{$\begin{array}{c}\text { Accessibility } \\
\text { intervals }\end{array}$} & \multicolumn{2}{|c|}{$\begin{array}{l}1^{\text {st }} \text { scenario } \\
\text { Consider the } \\
\text { time-distance } \\
\text { from one of the } \\
18 \text { existing NIME } \\
\text { ambulances to } \\
\text { one of the three } \\
\text { urgent care } \\
\text { services }\end{array}$} & \multicolumn{2}{|c|}{$\begin{array}{l}2^{\text {nd }} \text { scenario } \\
\text { Consider the } \\
\text { time-distance } \\
\text { from LSA and } \\
\text { EMRS, NIME } \\
\text { ambulances, } \\
\text { to one of the } \\
\text { three urgent } \\
\text { care services }\end{array}$} & \multicolumn{2}{|c|}{$\begin{array}{l}3^{\text {rd }} \text { scenario } \\
\text { Consider the } \\
\text { time-distance } \\
\text { from one of the } \\
18 \text { existing NIME } \\
\text { ambulances to a } \\
\text { medical-surgical } \\
\text { urgent care } \\
\text { service in Beja }\end{array}$} & \multicolumn{2}{|c|}{$\begin{array}{l}4^{\text {th }} \text { scenario } \\
\text { Consider the } \\
\text { time-distance } \\
\text { from LSA and } \\
\text { EMRS, NIME } \\
\text { ambulances, to a } \\
\text { medical-surgical } \\
\text { urgent care } \\
\text { service in Beja }\end{array}$} & \multicolumn{2}{|c|}{$\begin{array}{l}5^{\text {th }} \text { scenario } \\
\text { Consider the time- } \\
\text { distance from one } \\
\text { of the } 18 \text { existing } \\
\text { NIME ambulances } \\
\text { to the nearest } \\
\text { multipurpose } \\
\text { urgent care service }\end{array}$} & \multicolumn{2}{|c|}{$\begin{array}{c}6^{\text {th }} \text { scenario } \\
\text { Consider the time- } \\
\text { distance from LSA } \\
\text { and EMRS, NIME } \\
\text { ambulances, } \\
\text { to the nearest } \\
\text { multipurpose } \\
\text { urgent care service }\end{array}$} \\
\hline & \multicolumn{2}{|c|}{$\begin{array}{c}\sum \text { Resident } \\
\text { population } \\
(2011)\end{array}$} & \multicolumn{2}{|c|}{$\begin{array}{c}\sum \text { Resident } \\
\text { population } \\
(2011)\end{array}$} & \multicolumn{2}{|c|}{$\begin{array}{c}\sum \text { P Resident } \\
\text { population }(2011)\end{array}$} & \multicolumn{2}{|c|}{$\begin{array}{c}\sum \text { Resident } \\
\text { population } \\
(2011)\end{array}$} & \multicolumn{2}{|c|}{$\begin{array}{c}\sum \text { Resident } \\
\text { population }(2011)\end{array}$} & \multicolumn{2}{|c|}{$\begin{array}{c}\sum \text { Resident } \\
\text { population }(2011)\end{array}$} \\
\hline & No & $\%$ & No & $\%$ & No & $\%$ & No & $\%$ & No & $\%$ & No & $\%$ \\
\hline$<10$ & 39687 & 31 & 39748 & 31 & 26857 & 21 & 26913 & 21 & 0 & 0 & 0 & 0 \\
\hline$<20$ & 69853 & 55 & 48280 & 38 & 41099 & 32 & 30276 & 24 & 0 & 0 & 0 & 0 \\
\hline$<30$ & 101164 & 80 & 67036 & 53 & 63544 & 50 & 38562 & 30 & 1177 & 1 & 0 & 0 \\
\hline$<40$ & 120576 & 95 & 95568 & 75 & 90931 & 72 & 68678 & 54 & 6554 & 5 & 0 & 0 \\
\hline$<50$ & 124148 & 98 & 112827 & 89 & 105574 & 83 & 88255 & 70 & 16742 & 13 & 0 & 0 \\
\hline$<60$ & 126404 & 100 & 118746 & 94 & 118101 & 93 & 103906 & 82 & 66928 & 53 & 53481 & 42 \\
\hline$<70$ & 126560 & 100 & 124174 & 98 & 124915 & 99 & 114923 & 91 & 88981 & 70 & 70577 & 56 \\
\hline$<80$ & 126670 & 100 & 125518 & 99 & 126021 & 99 & 121185 & 96 & 114542 & 90 & 90117 & 71 \\
\hline$<90$ & 126692 & 100 & 126682 & 100 & 126458 & 100 & 123547 & 98 & 124179 & 98 & 106290 & 84 \\
\hline$<100$ & - & - & 126692 & 100 & 126571 & 100 & 124642 & 98 & 126183 & 100 & 119018 & 94 \\
\hline$<110$ & - & - & - & - & 126675 & 100 & 126586 & 100 & 126688 & 100 & 124070 & 98 \\
\hline$<120$ & - & - & - & - & 126692 & 100 & 126686 & 100 & 126692 & 100 & 125518 & 99 \\
\hline$<130$ & - & - & - & - & - & - & 126692 & 100 & - & - & 126692 & 100 \\
\hline
\end{tabular}

Source: Elaborated from data INE-RGP; DGS-Geosaúde; NIME.

Finally, in the case of municipalities whose access times are more unfavorable, it is necessary to reinforce alternative means of an emergency, such as aerial means. Regardless of the proposed solutions, it is worth emphasizing that the aging target population with mobility difficulties and lower-income prevalent in the Baixo Alentejo territory is always an obstacle to emergency services. Thus, the need to reinforce prevention and primary health services is emphasized to reduce the risk situations of populations.

\section{Collaborations}

Work conception and design: R Ferreira, NM Costa, EM Costa. Theoretical framework: R Ferreira, and EM Costa. Selection of variables, collecting data, selecting variables, and methodological implementation: R Ferreira and NM Costa. Discussion of results: R Ferreira, NM, Costa, and EM Costa. Conclusions: R Ferreira, NM, Costa, and EM Costa. 


\section{References}

1. Furtado C, Pereira J. Equidade e Acesso aos Cuidados de Saúde - Documento preparado para o PNS. Lisboa: Universidade Nova de Lisboa; 2010.

2. Barros P, coordenador. Políticas Públicas em Saúde: 2011 - 2014. Avaliação do Impacto. Lisboa: Nova Healthcare Initiative - Research/Universidade Nova de Lisboa; 2015.

3. Ribeiro V, Remoaldo P, Gutiérrez J, Ribeiro C. Acessibilidade e SIG no planeamento em saúde: uma abordagem baseada em modelos de alocação-localização. Revista Portuguesa de Estudos Regionais [serial on the Internet]. $20151^{\circ}$ Quadrimestre. [cited 2019 Nov. 29];38:1-16. Available from: http://www.apdr.pt/siteRPER/numeros/RPER38/38.1.pdf

4. Remoaldo P. Acessibilidade Física, Funcional e Económica aos Cuidados de Saúde. Atas do IV Congresso da Geografia Portuguesa - Geografia: Territórios de Inovação. Lisboa: Associação Portuguesa de Geógrafos; 2002.

5. Remoaldo P, Nogueira H, coordenadores. Desigualdades socioterritoriais e comportamentos em saúde. Lisboa: Edições Colibri; 2003.

6. Haynes R. Geographical access to health care. In: Haynes R. Access to Health Care. London: Routledge; 2003. p. 13-35.

7. Rodrigues APS. Introdução à geografia da saúde: território, saúde e bem-estar. Coimbra: Imprensa Nacional de Coimbra; 2014.

8. Donabedian A. Models for Organizing the Delivery of Personal Health Care Services and Criteria for Evaluating Them. Milbank Memorial Fund Quarterly 1972; 50(4, Pt 2):103-54.

9. Joseph AE, Phillips DR. Accessibility and Utilization: Geographical Perspectives on Health Care Delivery. New York: Harper and Row; 1984.

10. Frenk J. El concepto y la medición de accesibilidad. Salud Publica de Mexico 1985; 27(5):438-453.

11. Andersen R. Newman JF. Societal and Individual Determinants of Medical Care Utilization in the United States. The Milbank Memorial Fund Quarterly. Health and Society [serial on the Internet].1973[cited 2019 Nov. 29]; 51:95-124. Available from: https://doi. org/10.2307/3349613

12. Penchansky R, Thomas WJ. The concept of access: definition and relationship to consumer satisfaction. Med Care 1981; 19(2):127-140.

13. Sanchez RM, Ciconelli RM. Conceitos de acesso à saúde. Rev Panam Salud Publica 2012; 31(3):260-268.

14. Rodrigues APS. Acessibilidade e utilização dos serviços de saúde: ensaio metodológico em geografia da saúde [tese]. Coimbra: Faculdade de Letras da Universidade de Coimbra; 1993 [cited 2019 Sep 10]. Available from: https://eg.uc.pt/handle/10316/631

15. da Costa EM, da Costa NM, Louro A, Barata M. Geographies of eldery access to primary health care in the Lisbon Metropolitan Area - Portugal: a territory of differences. Saude soc [periódico na Internet].2020 [acessado 2019 Dez 12]; 29(2):13. Disponível em: DOI: https://doi.org/10.1590/s010412902020200108
16. Palma P, Marques da Costa E, Marques da Costa N. Disparidades regionais no acesso aos serviços de saúde em territórios de baixa densidade: os casos do Alentejo (Portugal) e Navarra (Espanha). In: Ribeiro Soares B, Marques da Costa N, Lima SC, Marques da Costa E, organizadores. Construindo Cidades Saudáveis:utopias e práticas. Uberlândia-Minas Gerais, Brasil: Ed. Assis; 2017. p. 449-483.

17. Dworkin R. Taling Rights Seriously. London: Duckworth;1977.

18. Gulliford M, Figueroa-Munoz J, Morgan M. Introduction. In: Gulliford M, Figueroa-Munoz J, Morgan M. Access to Health Care. London: Routledge; 2003.p. 1-12.

19. Gillon R. Philosophical Medical Ethics. In: Gillon R Philosophical Medical Ethics. Chichester: John Wiley; p. 86-99.

20. Gulliford M. Equity and access to health care. In: Gulliford M. Access to Health Care. London: Routledge; 2003. p. 36-60.

21. Santinha G. Serviços de interesse geral e coesão territorial: o caso da saúde [dissertação]. Aveiro: Universidade de Aveiro; 2014.

22. Commission of The European Communities. A Quality Framework for Services of General Interest in Europe. Brussels, 20.12.2011 COM (2011) 900 final. [cited 2019 Aug 29]. Available from: https://ec.europa.eu/ archives/commission_2010-2014/president/news/ speeches-statements/pdf/20111220_1_en.pdf

23. Marques da Costa E, Palma P, Rauhut D, Humer A, Constantin D, Velasco X. What indicators to use when measuring Services of General Interest? Europa XXI 2013; 23:7-28. (Polish Academy of Sciences)

24. Commission of The European Community. Green paper on services of general interest, $\mathrm{COM} / 2003 / 0270$ final Brussels, 21.5.2003, $\operatorname{COM(2003)~} 270$ final [cited 2019 Aug. 29]. Available from: https://eur-lex. europa.eu/legal-content/EN/TXT/?uri=CELEX:52003DC0270

25. Jonard F, Lambotte M, Ramos F, Terres JM, Bamps C. Delimitations of rural areas in Europe using criteria of population density, remoteness and land cover. Luxemburg: European Commission Joint Research Centre Institute for Environment and Sustainability; 2009.

26. Instituto Nacional de Emergência Médica de Portugal (INEM). O Sistema Integrado de Emergência Médica. Lisboa: Ministério da Saúde; 2018. [cited 2018 Sep 22]. Available from: https://www.inem.pt/2017/05/25/ centro-de-orientacao-de-doentes-urgentes/

27. Instituto Nacional de Emergência Médica de Portugal (INEM). Relatório anual: Meios de Emergência Médica 2016. Lisboa: Gabinete de Planeamento e Controlo de Gestão do INEM; 2017.

28. Instituto Nacional de Emergência Médica de Portugal (INEM). Relatório anual: Meios de Emergência Médica 2017. Lisboa: Gabinete de Planeamento e Controlo de Gestão do INEM; 2018.

29. Grone O, Garcia-Barbero M. A position paper of the WHO European office for integrated health care services. International Journal of Integrated Care 2000; 1: $1-10$ 
30. Entidade Reguladora da Saúde. Estudo Sobre o desempenho das Unidades Locais de Saúde, Porto: ERS -Ministério da Saúde; 2015. [cited 2018 Sep 22]. Available from: https://www.ers.pt/uploads/writer_file/ document/1298/Estudo_sobre_o_Desempenho_das_ ULS_-_final.pdf

31. Adminstração Central do Sistema de Saúde (ACSS). Acesso a cuidados de saúde nos estabelecimentos do SNS e entidades convencionadas. Lisboa: Ministério da Saúde; 2017.

32. Morais P. Os SIG no processo de criação de instrumentos de apoio à decisão. [dissertação] Lisboa: Faculdade de Letras da Universidade de Lisboa; 2013.

Article submitted 18/04/2020

Approved 11/08/2020

Final version submitted 13/08/2020

Chief editors: Maria Cecília de Souza Minayo, Romeu Gomes, Antônio Augusto Moura da Silva 